\title{
Assessment of ship accident risk in the east Surabaya shipping channel using formally safety assessment method
}

\author{
Okol Sri Suharyo *, Ayip Rivai Prabowo and Mardi Winoelyo \\ Indonesia Naval Technology College STTAL Surabaya Indonesia.
}

Global Journal of Engineering and Technology Advances, 2022, 10(01), 022-032

Publication history: Received on 21 November 2021; revised on 31 December 2021; accepted on 02 January 2022

Article DOI: https://doi.org/10.30574/gjeta.2022.10.1.0175

\begin{abstract}
Surabaya East Shipping Channel is part of the busiest shipping lanes west of Surabaya in Indonesia after inflows in Tanjung Priok. With the navigation, channel conditions are long and narrow plus the number of flows in and out of the harbor boats is very vulnerable to accidents resulting in either the stranded sea, ship collision, or other accident types, which would harm the cruise interocular. By looking at the facts above, so it is necessary to conduct a more in-depth study of the accident risk assessment of the shipping channel east of Surabaya. This study aimed to obtain any kind of accident that has a high risk in the port of Surabaya, to know what impact may result from an accident with a high risk and gain steps that can be taken to reduce accidents in Surabaya East Shipping Channel by using Method Formal Safety Assessment (FSA). Of the six types of accidents that occur, there are three accidents with the highest risk of stranded ships, human accidents, collisions with ships dock at the time of sailing ships and dock. The impact of the third accident caused huge material losses. To reduce the risk of all three types of accidents was measured Implied Cost of Averting a Risk (ICAR), the lowest of any risk reduction options. Reduction of risk to do is impose a routine patrol and installation of signs groove ICAR ports have amounted to 234 million, giving a human rescue training vessel which has a value of 112 million ICAR and the latter is tightened harbor area with ICAR 84 million so that unauthorized parties do not enter in the harbor area.
\end{abstract}

Keywords: Formally Safety Assessment (FSA); Shipping Channel; Sea Accident

\section{Introduction}

Geographically Shipping Channel East Surabaya is located in the Madura Strait in position: 0711'55 "S - 112º47'10"T the circumstances surrounding the coastal low marshy harbor. To enter the Port of Tanjung Perak, there are two regular shipping lanes or commonly used and referred to as the Shipping Channel Surabaya East and West Surabaya Shipping Channel. The East Flow Sailing Surabaya is used for ships that have a small draft (draft 1-4 meters) so that the intensity of the incoming or outgoing ships Shipping Channel East Surabaya in East Java to the island other than a bit, one of the factors for Eastern Shipping Channel Surabaya very risky because Kalimas river empties towards the harbor which resulted in the silting-silting to use cruise line that will have an impact for cruise ships with large drafts. Based on these facts, the majority of ships with large drafts (4-9 meters) would prefer to skip the Shipping Channel West Surabaya, Surabaya East Shipping Channel is an alternative groove to enter the Port of Tanjung Perak 19.5 nautical miles in length, width 100 meters with a depth varying between 4 to 7 meters. With the navigation, channel conditions are long and narrow plus the number of flows in and out of the harbor boats is very vulnerable to accidents resulting in either the stranded sea, ship collision, or other types of accidents such as fire, work accidents, and others which would harm the cruise national.

\footnotetext{
* Corresponding author: Okol Sri Suharyo

Indonesia Naval Technology College STTAL Surabaya Indonesia.

Copyright (C) 2022 Author(s) retain the copyright of this article. This article is published under the terms of the Creative Commons Attribution Liscense 4.0.
} 


\section{Material and methods}

Completing this final task required a variety of theories that will support and facilitate working, ranging from the concept of risk that gives insight into the risk, hazard (hazard), or adverse events. Besides, the concept of risk management is also important because here gives us an idea of how risks are identified and as much as possible to reduce and even eliminate touches. Of course, the basis of this theory will also be introduced models Safety Formal Assessment (FSA) as a method to resolve this thesis in addition to any additional theories related to shipping lanes east of Surabaya.

The steps taken by the company in implementing risk management is to first identify the risks that may be experienced by the company, after identifying it conducted an evaluation of each risk in terms of the value of risk (severity) and frequency. The last stage is risk control. The risk management phase is divided into two namely physical control (the risk is eliminated, minimized risk) and financial control (retained risk, the risk is transferred). Risk management consists of three components, namely:

- Identification and analysis of risk

- Evaluation of risk

- $\quad$ Reduction of risk and control risk (RiskTreatment)

Identify hazards (hazard identification), in the form of a list of all relevant accident scenarios with potential causes and consequences, as an answer to the question "what errors may occur. The goal is to identify a list of hazards and set priorities scenario is determined by the level of risk of the issue being discussed. This objective can be achieved by using standard techniques to identify hazards that play a role in the crash, by filtering these hazards through a combination of existing data and opinion and to review the general model that was created when defining the problem. The approach used for hazard identification, generally a combination of creative and analytical techniques, which aim to identify all relevant hazards. A rough analysis of the causes and consequences of each category of accidents by using certain techniques, such as fault tree analysis, event tree analysis, failure mode and effect analysis (FMEA), hazard and operability studies (HAZOP), what-if analysis technique, and risk contribution tree (RCT), which is selected according to the issues discussed.

\subsection{Risk Assessment}

These objectives can be achieved by using techniques appropriate to the risk model that was made and attention is focused on a high-risk assessment. The value in question is the level (level) risk, which can be divided into:

- Risks that cannot be justified or accepted, except in exceptional circumstances (Intolerable).

- Risks that have been made so small that it does not need further precautions (negligible).

- The risk that the level is between the Intolerable and negligible levels (as low as reasonably practicable = ALARP).

\subsection{Selection of Control Risks}

The purpose of the step of Selection of Control Risks is to propose effective and practical RCOs, through four steps following principles:

- Focusing on the risks that require control, filter the output from step Risk Assessment, so focus only on the area's most in need of control risk.

- Identify measures to control potential risks (risk control measures = RCMS).

- Evaluating the effectiveness of the RCMS in reducing the risk of re-evaluating the 2nd step.

- Grouping RCMS into a practical option.

\subsection{Assessment of Costs and Benefits}

The purpose of the Assessment of Costs and Benefits is to identify and compare the benefits and costs of implementing each RCOs were identified. Costs (costs) must be expressed in the life cycle costs (life cycle costs), which includes early (initial), operation (operating), training (training), inspection (inspection), certification (certification), deactivation (decommission), etc. While the benefits (benefits) may include a reduction in mortality (fatalities), injuries/losses 
(injuries), accidents (casualties), environmental damage and cleanup (environmental damage and clean-up), compensation (indemnity) by a third party responsible, and an increase in the average age (average life) of the ship.

The output of the Assessment of Costs and Benefits step is composed of:

- $\quad$ Costs and benefits for each RCO are identified in step 3.

- Costs and benefits to the RCO of concern (which is most affected by the problem).

- Economic usefulness stated in the corresponding index.

The equation used to solve this problem is to Index Cost of Averting a Risk (ICAR) as given in Equation below:

$$
\mathrm{ICAR}=\frac{(\Delta \mathrm{C}-\Delta \mathrm{B})}{\text { Decreased risk }}(\mathrm{EQU} .2 .1)
$$

Where is:

ICAR = Implied cost of averting a risk (risk reduction Cost Index)

$\Delta \mathrm{C}=$ Cost of risk control

$\Delta \mathrm{B}=$ economic benefits of the application of risk control

Decreased risk $=$ Decreased risk after controlling held

\subsection{Recommendations for Decision Step}

The purpose of this step is to define recommendations that should be given to the man-taker-making, in a way that can be audited and can be tracked.

Recommendations are based on:

- Comparison and sorting rate of all the dangers and causes.

- Comparison and sorting level of risk control options as a function of the combined costs and benefits.

- Identification of risk control options that keep the risk as low as possible so nonsensical to be implemented.

Recommendations should be provided in a format that can be understood by all parties, regardless of experience. Submission of recommendations as a result of a process of the FSA should be given the right time and have access to the relevant supporting documents with a mechanism that includes a comment.

The output of this step is comprised of:

- An objective comparison of the alternative options, based on the risk reduction potential and usefulness of economic (cost-effectiveness), according to the laws or rules that are being reviewed or re-developed.

- Feedback information to review the results of given natural previous steps.

Table 1 Criteria Consequences

\begin{tabular}{|c|c|c|c|c|}
\hline Scale & Man & Property & Environment & Stakeholder \\
\hline $\mathrm{CO}$ & $\begin{array}{l}\text { Not significant } \\
\text { (possibility very small } \\
\text { wounds wound) }\end{array}$ & $\begin{array}{l}\text { not } \\
\text { significant } \\
\text { (NZ\$0- } \\
10,000)\end{array}$ & $\begin{array}{l}\text { not significant (no } \\
\text { damage mean ) }(\mathrm{NZ} \$ 0 \text { - } \\
10,000)\end{array}$ & not significant (NZ\$0-10,000) \\
\hline $\mathrm{C} 1$ & Small (one wound light) & $\begin{array}{l}\text { Small } \\
(\mathrm{NZ} \$ 10 \mathrm{~K} \\
100 \mathrm{~K})\end{array}$ & $\begin{array}{l}\text { Small (little spill } \\
\text { operational) (NZ\$10K- } \\
100 \mathrm{~K})\end{array}$ & $\begin{array}{l}\text { Small Term revenue losses short } \\
(\mathrm{NZ} \$ 10 \mathrm{~K}-100 \mathrm{~K})\end{array}$ \\
\hline
\end{tabular}




\begin{tabular}{|c|c|c|c|c|}
\hline $\mathrm{C} 2$ & $\begin{array}{lrr}\begin{array}{l}\text { Medium (many } \\
\text { injuries }\end{array} & \text { minor } \\
\text { occurrence } & & \text { one } \\
\text { injuries) } & & \text { severe }\end{array}$ & $\begin{array}{l}\text { Medium } \\
(\mathrm{NZ} \$ 100 \mathrm{~K}- \\
1 \mathrm{M})\end{array}$ & $\begin{array}{l}\text { Medium (spill capable } \\
\text { spread in the area } \\
\text { port) }(\mathrm{NZ} \$ 100 \mathrm{~K}-1 \mathrm{M})\end{array}$ & $\begin{array}{l}\text { Medium (cessation shipping } \\
\text { temporary or extension shipping } \\
\text { restrictions) (NZ } \$ 100 \mathrm{~K}-1 \mathrm{M})\end{array}$ \\
\hline C3 & $\begin{array}{l}\text { Weight (Lots severe } \\
\text { injury or one death) }\end{array}$ & $\begin{array}{l}\text { Weight } \\
(\mathrm{NZ} \$ 1 \mathrm{M}- \\
10 \mathrm{M})\end{array}$ & $\begin{array}{l}\text { Weight (Pollution can } \\
\text { out of Port potentially } \\
\text { damage } \\
\text { environment) } \\
\text { (NZ\$1M-10M) }\end{array}$ & $\begin{array}{l}\text { Weight National scope, Groove is } \\
\text { closed temporarily from a cruise } \\
\text { to someday. The following does } \\
\text { not occur trade) (NZ\$1M-10M) }\end{array}$ \\
\hline C4 & $\begin{array}{l}\text { Catastrophic/major } \\
\text { disasters (Lots cause of } \\
\text { death }\end{array}$ & $\begin{array}{l}\text { Disaster } \\
\text { great }(10 \mathrm{M}+)\end{array}$ & $\begin{array}{l}\text { Disaster (occurs oil } \\
\text { spill } \\
\text { large / inter-country } \\
\text { very damaging the } \\
\text { environment) }(10 \mathrm{M}+)\end{array}$ & $\begin{array}{l}\text { Disaster (The scope already } \\
\text { international, harbour closed, } \\
\text { disrupted shipping for some } \\
\text { time. Serious and occurred } \\
\text { within long, not occurs trade) } \\
(10 \mathrm{M}+)\end{array}$ \\
\hline
\end{tabular}

Source: Port \& Harbour Risk Assessment \& Safety Management System

Table 2 Criteria Frequency

\begin{tabular}{|l|l|l|}
\hline Category & Description (AS/NZS 4360) & Definition \\
\hline F1 & Frequent & An event occurs once a week to once a year operation \\
\hline F2 & Likely & An event occurs once a year to once in 10 years of operation \\
\hline F3 & Possible & $\begin{array}{l}\text { An event occurs once in } 10 \text { years of operation up to } 100 \text { within a year } \\
\text { of operation }\end{array}$ \\
\hline F4 & Unlikely & An event occurs less than 1 time in 100 years operate \\
\hline F5 & Rare & $\begin{array}{l}\text { Genesis less than } 1000 \text { years of operation } \text { (eg: Possible occur in ports } \\
\text { elsewhere in the world. }\end{array}$ \\
\hline
\end{tabular}

Source: Port \& Harbour Risk Assessment \& Safety Management System

Table 3 Risk Matrix

\begin{tabular}{|l|l|l|l|l|l|l|}
\hline \multirow{5}{*}{ Consequence } & $\mathbf{C 4}$ & $\mathbf{5}$ & $\mathbf{6}$ & $\mathbf{7}$ & $\mathbf{8}$ & $\mathbf{1 0}$ \\
\cline { 2 - 7 } & $\mathrm{C} 3$ & 4 & 5 & 6 & 7 & 9 \\
\cline { 2 - 7 } & $\mathrm{C} 2$ & 3 & 3 & 4 & 6 & 8 \\
\cline { 2 - 7 } & $\mathrm{C} 1$ & 1 & 2 & 2 & 3 & 6 \\
\cline { 2 - 7 } & $\mathrm{C} 0$ & 0 & 0 & 0 & 0 & 0 \\
\hline Frequency & F5 & F4 & F3 & F2 & F1 \\
\hline
\end{tabular}

Specification: 0 \& 1 Risk negligible, 2 \& 3 Low Risk, 4 \& 5 Regions of Low as Reasonably Practicable As Area (ALARP), 6 higher risk, 7 \& 8 Significant Risk, 9 \& 10 high risk

\subsection{Formal Safety Assessment}

Formal Safety Assessment (FSA) is a methodology or process that is a rational, structured, and systematic way to assess risks associated with activities in the field of maritime (shipping) and to evaluate the cost (cost) and benefits (benefits) of several control options risk (risk control options), using risk analysis and cost-benefit assessment (International Maritime Organization, 2002). The FSA aims to reduce the risks while increasing the safety of shipping (marine safety), which includes protection against the soul (life), health (health), aquatic environments (marine environment), and property (property). 


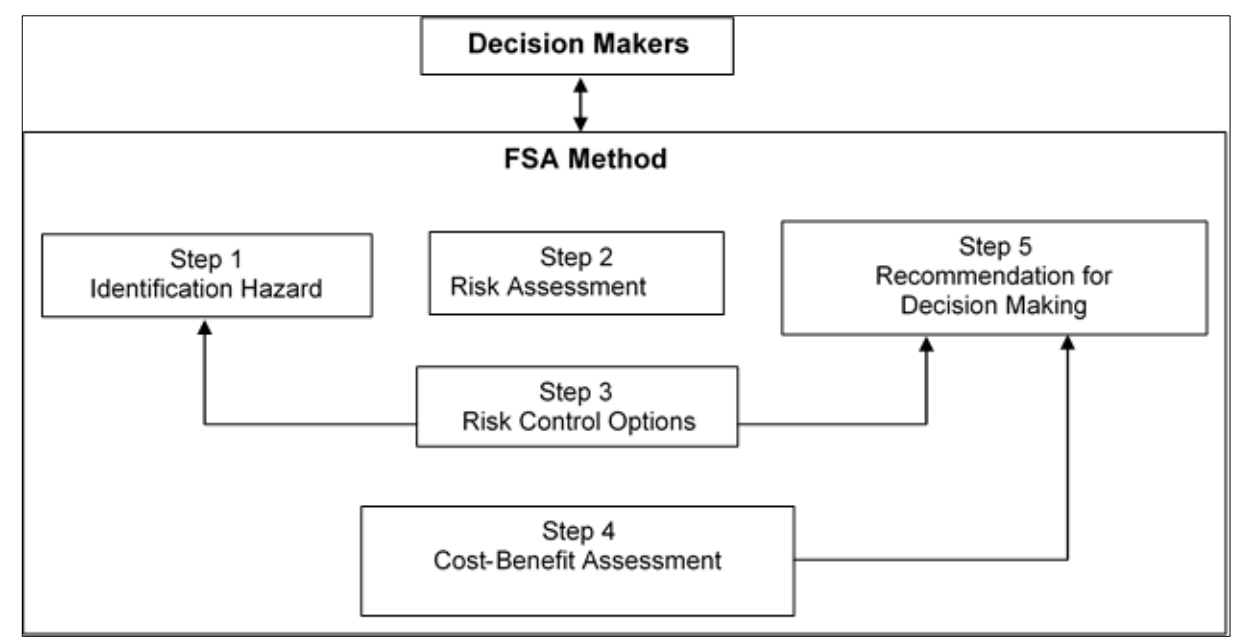

Figure 1 The framework of the Formal Safety Assessment

\section{Research result}

At the beginning of data collection, the one that is needed is how much the amount of traffic passes through the vessel Eastern Shipping Channel heading to the port of Tanjung Perak. In Table Data Ships passing APTS give an idea of it. This data is the number of vessels passing through the shipping lanes east of Surabaya during the period of 5 years ie 2009 to 2013. After knowing the general description of the conditions at the Port of Tanjung Perak, the next most important thing is to present the data of accidents that have occurred. Table 4.2 shows data on accidents that occurred in Surabaya East Shipping Channel (ATPS) that shows the number of occurrences of an event taken from 2009 to 2013.

Table 4 Ship Accident Data in APTS

\begin{tabular}{|l|l|c|c|c|c|c|c|}
\hline \multirow{2}{*}{ No } & \multirow{2}{*}{ Type of accident } & \multicolumn{5}{|c|}{$\begin{array}{c}\text { The number of events per year } \\
\text { (Frequency) }\end{array}$} & Amt \\
\cline { 3 - 9 } & & $\mathbf{2 0 0 9}$ & $\mathbf{2 0 1 0}$ & $\mathbf{2 0 1 1}$ & $\mathbf{2 0 1 2}$ & $\mathbf{2 0 1 3}$ & \\
\hline A & Collision (ships with dock) & 1 & 0 & 2 & 1 & 0 & 4 \\
\hline B & Collision (ship by ship) & 0 & 0 & 2 & 1 & 0 & 3 \\
\hline C & sink & 1 & 1 & 1 & 0 & 0 & 3 \\
\hline D & fire & 1 & 0 & 1 & 0 & 1 & 3 \\
\hline E & Human accident & 2 & 3 & 2 & 1 & 1 & 9 \\
\hline F & aground & 2 & 1 & 1 & 1 & 0 & 5 \\
\hline The amount & 7 & 5 & 9 & 4 & 2 & 26 \\
\hline
\end{tabular}

Source: Directorate of Planning and Control (DIT. Rendal), Main Adpel Tg. Perak

Table 5 Data of Vessels passing through APTS

\begin{tabular}{|c|c|c|c|}
\hline \multirow{2}{*}{ No } & \multirow{2}{*}{ Year } & \multicolumn{2}{|c|}{ The amount } \\
\cline { 3 - 4 } & & Unit & GT \\
\hline 1 & 2009 & 2100 & 551.259 \\
\hline 2 & 2010 & 2109 & 470.625 \\
\hline 3 & 2011 & 2190 & 309.006 \\
\hline 4 & 2012 & 2328 & 233.565 \\
\hline 5 & 2013 & 1935 & 172.257 \\
\hline
\end{tabular}

Source: Office of Tanjung Perak Port Authority Main 
This data is needed to analyze the pattern and type of accidents that occurred in Surabaya East Shipping Channel that will be included in the form of frequency criteria.

\subsection{Determine Value Criteria Consequences}

Data are generally qualitative damage, so it can be used in the method Formal Safety Assessment (FSA), the data must be converted/translated into figures. The results of these interviews are the consequences of the accident criteria ranging from the lightest to the heaviest that has defined the criteria Consequences Port \& Harbour Risk Assessment and Safety Management System. Interviews were conducted because the nominal value of the consequences of an accident at each port is different for each port has its groove characteristics.

Table 6 Criteria for Consequences and their Values

\begin{tabular}{|c|c|c|c|c|}
\hline Scale & Human & Property & Environment & Stakeholder \\
\hline $\mathrm{CO}$ & $\begin{array}{l}\text { not significant } \\
\text { possibility very small } \\
\text { wounds wound }(0-1 \\
\text { million) }\end{array}$ & $\begin{array}{l}\text { not } \\
\text { significant } \\
(0-14 \\
\text { million })\end{array}$ & 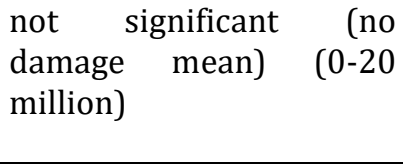 & not significant ( $0-14$ million) \\
\hline $\mathrm{C} 1$ & $\begin{array}{l}\text { Small (one wound } \\
\text { light) (1 million }-5 \\
\text { million) }\end{array}$ & $\begin{array}{l}\text { Small } \\
\text { (14juta- } \\
500 \mathrm{~m})\end{array}$ & $\begin{array}{l}\text { Small (A little spill } \\
\text { operational) }(20 \text { million - } \\
1 \mathrm{M})\end{array}$ & $\begin{array}{l}\text { Small Term revenue losses } \\
\text { Short ( } 14 \text { million - } 500 \text { million) }\end{array}$ \\
\hline $\mathrm{C} 2$ & $\begin{array}{l}\text { Medium (many minor } \\
\text { injuries or } \begin{array}{r}\text { one } \\
\text { occurrence }\end{array} \\
\text { injuries) (5 million-10 } \\
\text { million) }\end{array}$ & $\begin{array}{l}\text { Moderate } \\
(500 \mathrm{~m}-4 \mathrm{M})\end{array}$ & $\begin{array}{l}\text { Medium (spill capable } \\
\text { spread in the area port) } \\
(1 \mathrm{M}-5 \mathrm{M})\end{array}$ & $\begin{array}{l}\text { Moderate (Cessation shipping } \\
\text { temporary or extension shipping } \\
\text { restrictions) }(500 \mathrm{~m}-4 \mathrm{M})\end{array}$ \\
\hline C3 & $\begin{array}{l}\text { Weight (Lots severe } \\
\text { injury or one death) } \\
(10 \text { million - } 25 \\
\text { million) }\end{array}$ & $\begin{array}{l}\text { Great } \quad(4 \mathrm{M}- \\
14 \mathrm{M})\end{array}$ & $\begin{array}{l}\text { Great (Pollution that can } \\
\text { out of port potentially } \\
\text { damage the environment) } \\
(5 \mathrm{M}-20 \mathrm{M})\end{array}$ & $\begin{array}{l}\text { Great National scope, The port is } \\
\text { closed temporarily of cruise } \\
\text { untukbeberapa day. ( } 4 \mathrm{M}-14 \mathrm{M})\end{array}$ \\
\hline $\mathrm{C} 4$ & $\begin{array}{l}\text { Catastrophic / bench } \\
\text { ana large (Lots cause of } \\
\text { death }(25 \text { million }+)\end{array}$ & $\begin{array}{l}\text { Disaster } \\
\text { great }(14 \mathrm{M} \\
+)\end{array}$ & $\begin{array}{l}\text { Disaster (occurs oil spill } \\
\text { large / inter-country very } \\
\text { damaging the } \\
\text { environment }(20 \mathrm{M}+)\end{array}$ & $\begin{array}{l}\text { Disaster (The scope already } \\
\text { international, harbour closed, } \\
\text { disrupted shipping for some } \\
\text { time. }(14 \mathrm{M}+)\end{array}$ \\
\hline
\end{tabular}

The values in Table Criteria consequences and magnitude of this value is in addition based on the maximum value of an economic value criterion consequences become the highest value is also determined by estimating the value of the damage at each level there are consequences.

On this occasion will also be shown how the risk assessment is carried out so that we get the expected risk level. For this purpose, the risk that the value previously obtained value is then taken and put into a simpler table, which aims to assist in the process of weighting later. 
Table 7 Score on Each Genesis

\begin{tabular}{|c|c|c|c|c|c|c|c|c|c|c|c|c|c|c|c|}
\hline \multirow{3}{*}{ 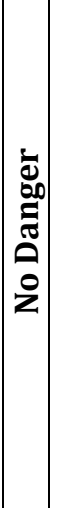 } & \multirow{3}{*}{ 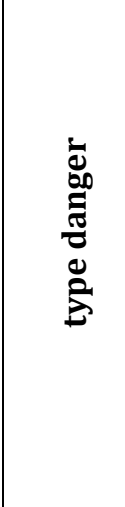 } & \multirow{3}{*}{ 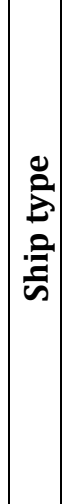 } & \multirow{3}{*}{ 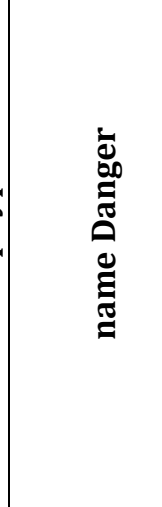 } & \multirow{3}{*}{ 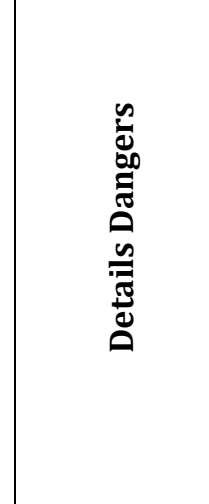 } & \multirow{3}{*}{ Possible Causes } & \multicolumn{5}{|c|}{$\begin{array}{c}\text { Consequences Greatest } \\
\text { Opportunity }\end{array}$} & \multicolumn{5}{|c|}{ Consequences possibility Worst } \\
\hline & & & & & & \multirow[b]{2}{*}{ 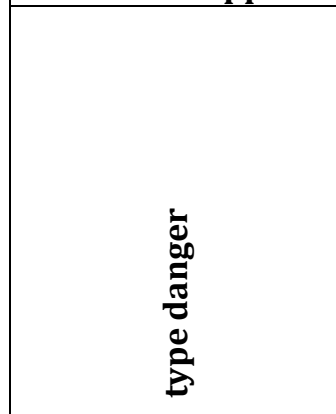 } & \multicolumn{4}{|c|}{\begin{tabular}{|c|} 
Hazards \\
Impacts \\
Assessment
\end{tabular}} & \multirow[b]{2}{*}{ 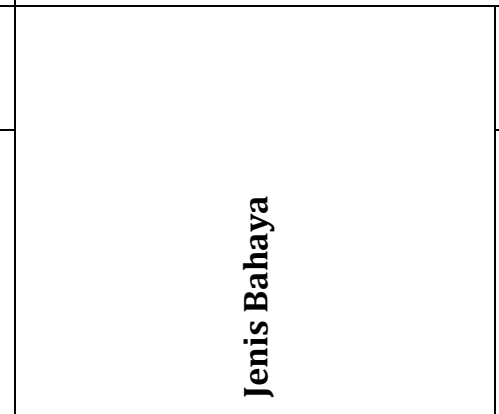 } & \multicolumn{4}{|c|}{$\begin{array}{c}\text { Hazards } \\
\text { Impacts } \\
\text { Assessment }\end{array}$} \\
\hline & & & & & & & 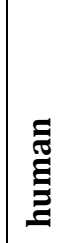 & 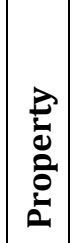 & 穿 & $\begin{array}{l}\frac{\dot{d}}{0} \\
\frac{0}{0} \\
\frac{\pi}{0} \\
\frac{\pi}{\pi} \\
\text { ஸे }\end{array}$ & & 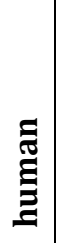 & 离 & 䒿 & 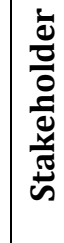 \\
\hline 1 & $\begin{array}{l}\text { A) } \\
\text { ollision }\end{array}$ & hip & $\begin{array}{l}\text { collision } \\
\text { ship with } \\
\text { dock }\end{array}$ & $\begin{array}{l}\text { ship collision } \\
\text { with } \\
\text { port } \\
\text { when will } \\
\text { berthing }\end{array}$ & $\begin{array}{l}\text { The engine/motor drive } \\
\text { Not functioning perfectly. } \\
\text { The vessel is currently docked } \\
\text { dark. } \\
\text { Do not understand the situation } \\
\text { Waters or due to currents. } \\
\text { failed to consider } \\
\text { between speed, power } \\
\text { And the weight of the vessel. } \\
\text { equipment } \\
\text { the ship is not working properly } \\
\text { (navigation, propulsion) Human } \\
\text { Error (Pilot, Tugmaster) }\end{array}$ & $\begin{array}{l}\text { Slight damage } \\
\text { Bow or skin plate. } \\
\text { minor damage } \\
\text { dock or system } \\
\text { fender }\end{array}$ & 6 & 0 & 0 & 3 & $\begin{array}{l}\text { Serious damage to the outer } 6 \\
\text { plate of the ship. } \\
\text { serious damage } \\
\text { on the dock / } \\
\text { fender }\end{array}$ & & 0 & 0 & 0 \\
\hline 2 & $\begin{array}{l}\text { B) } \\
\text { ollision }\end{array}$ & hip & $\begin{array}{l}\text { collision } \\
\text { around } \\
\text { port }\end{array}$ & $\begin{array}{l}\text { ollision } \\
\text { ccurred } \\
\text { etween } \\
\text { hips going } \\
\text { nd out } \\
\text { ort }\end{array}$ & 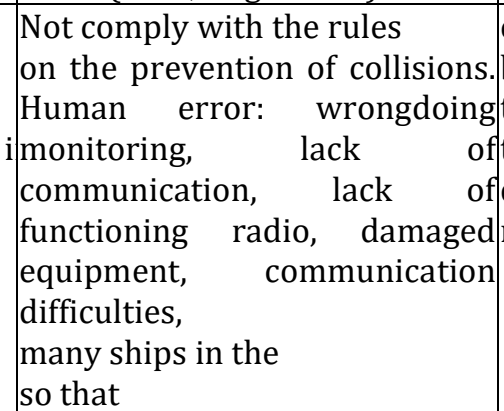 & $\begin{array}{l}\text { occurs nudge } \\
\text { between two small on } \\
\text { the ship, } \\
\text { there is a delay } \\
\text { departure or } \\
\text { mooring. }\end{array}$ & 0 & 3 & 0 & 3 & $\begin{array}{l}\text { Serious damage to the ship, } 0 \\
\text { there were no fatalities, } \\
\text { occurred pollution due to oil } \\
\text { spills, explosions, and fires, } \\
\text { closure } \\
\text { port }\end{array}$ & & 0 & 0 & 0 \\
\hline
\end{tabular}




\begin{tabular}{|c|c|c|c|c|c|c|c|c|c|c|c|c|c|}
\hline & & & & & views so less & & & & & & & & \\
\hline 3 & $\begin{array}{l}\text { C) } \\
\text { ink }\end{array}$ & hip & sinking ship & \begin{tabular}{|l|} 
The ship sank \\
after \\
intruding \\
seawater
\end{tabular} & $\begin{array}{l}\text { Leakage of stomach skin, } \\
\text { condition Bakap old, ballast } \\
\text { system that does not work, } \\
\text { overloading, crew skills of } \\
\text { science and unloading less. } \\
\text { Unwillingness ABK calculates } \\
\text { the stability of the ship. Searches } \\
\text { damaged, the quality of the mall } \\
\text { ship standard, non-marine steel } \\
\text { plate }\end{array}$ & $\begin{array}{l}\text { The partially } \\
\text { submerged ship, } \\
\text { cargo damaged, can } \\
\text { be reappointment }\end{array}$ & 6 & 0 & 3 & $\begin{array}{l}\text { The ship sank, pollution occurs } 0 \\
\text { because of the oil spill, occurred } \\
\text { casualties, the port is closed } \\
\text { temporarily }\end{array}$ & 0 & 0 & 0 \\
\hline 4 & D) & $\begin{array}{l}\text { ll } \\
\text { hip }\end{array}$ & $\begin{array}{l}\text { ship } \\
\text { burning }\end{array}$ & 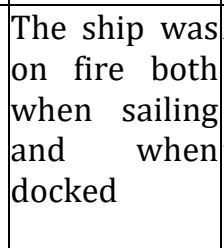 & $\begin{array}{l}\text { ABK low mentality, fire fighting } \\
\text { equipment no / less, fewer } \\
\text { extinguishers, lack crew } \\
\text { training, the crew left the flame } \\
\text { is still small and does not fire } \\
\text { immediately }\end{array}$ & \begin{tabular}{|l|} 
Burned on a small 0 \\
scale, \\
passenger/crew \\
minor injuries, delays, \\
or mooring departure
\end{tabular} & 3 & 0 & 3 & $\begin{array}{l}\text { Burned a large scale, the } 0 \\
\text { possibility of sinking, cause loss } \\
\text { of life, pollution occurs due to } \\
\text { spillage of the port }\end{array}$ & 0 & 0 & 0 \\
\hline 5 & $\begin{array}{l}\text { E) } \\
\text { fuman } \\
\text { ccident }\end{array}$ & hip & \begin{tabular}{|l} 
Human \\
accidents \\
vessel
\end{tabular} & $\begin{array}{l}\text { By the time } \\
\text { the bases ship } \\
\text { will } \\
\text { propped. } \\
\text { some people } \\
\text { fall into the } \\
\text { sea/contact } \\
\text { rope troops }\end{array}$ & $\begin{array}{l}\text { Ships can not calm (weather). So } \\
\text { the big waves/wind exceeds the } \\
\text { criteria dock. The pilot boat } \\
\text { made a mistake. Made a mistake } \\
\text { installing stairs. Less careful in } \\
\text { stepping/pull rope troops }\end{array}$ & $\begin{array}{l}\text { The possibility exists } 3 \\
\text { that fall into the } \\
\text { water/sea, } \\
\text { experienced } \\
\text { minor injuries, } \\
\text { bruises } \\
\text { etc. }\end{array}$ & 3 & 0 & 3 & $\begin{array}{l}\text { The possibility exists that would } 6 \\
\text { fall into the water/sea, broken } \\
\text { bones, no casualties }\end{array}$ & 7 & 3 & 6 \\
\hline 6 & \begin{tabular}{|l} 
F) \\
ground
\end{tabular} & hip & $\begin{array}{l}\text { aground in } \\
\text { The flow } \\
\text { port }\end{array}$ & \begin{tabular}{|l|} 
By the time \\
the ship \\
enter \\
port \\
ship \\
experience \\
aground \\
\end{tabular} & $\begin{array}{l}\text { Less precise in } \\
\text { estimate draft vessel } \\
\text { and depth, presence } \\
\text { remnants of the pier } \\
\text { construction } \\
\text { which makes shallow, narrow } \\
\text { grooves generally, silting } \\
\text { because of silt, less proficient in } \\
\text { processing moving ships, bad } \\
\text { weather (currents and winds), } \\
\text { and fewer danger signs. }\end{array}$ & $\begin{array}{l}\text { occurs grooves } \\
\text { under the boat, } \\
\text { damage to the plates } \\
\text { that allow water } \\
\text { entry, as well as } \\
\text { delays }\end{array}$ & 6 & 0 & 6 & $\begin{array}{l}\text { Leaking plate on the hull. Leak } 4 \\
\text { and } \\
\text { Increased draft. there must be } \\
\text { withdrawal for } \\
\text { release the ship, the ship } \\
\text { aground, the possibility of } \\
\text { damage to the charge at the time } \\
\text { the machine is not working }\end{array}$ & 6 & 2 & 4 \\
\hline
\end{tabular}


Table 8 Risk early type of accident

\begin{tabular}{|c|c|c|c|c|c|c|c|c|}
\hline \multirow[b]{2}{*}{ event } & \multicolumn{4}{|c|}{ The possibility of the consequences } & \multicolumn{4}{|c|}{ Consequences possibility Worst } \\
\hline & 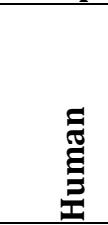 & 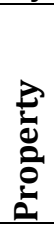 & 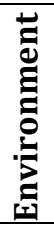 & 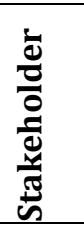 & $\underset{\Xi}{\Xi}$ & $\begin{array}{l}\overrightarrow{0} \\
\vdots \\
\vdots \\
0 \\
0\end{array}$ & 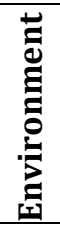 & 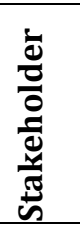 \\
\hline Collision ship with dock & 6 & 0 & 0 & 3 & 6 & 0 & 0 & 0 \\
\hline Collision (Ship to Ship) & 0 & 3 & 0 & 3 & 0 & 0 & 0 & 0 \\
\hline $\operatorname{sink}$ & 3 & 6 & 0 & 3 & 0 & 0 & 0 & 0 \\
\hline Fire & 0 & 3 & 0 & 3 & 0 & 0 & 0 & 0 \\
\hline Human accident & 3 & 3 & 0 & 3 & 6 & 7 & 3 & 6 \\
\hline aground & 6 & 6 & 0 & 6 & 4 & 6 & 2 & 4 \\
\hline
\end{tabular}

To sort where the highest risk in addition to the criteria used frequency and consequences also need to provide the weight that each type of accident can be sorted proportionally so that the required weighting between accidents that occur in humans and others such as boats, equipment, and others like Table value Weighting safety Scoring 0.6 and 0.4 is quite rational if we put human safety as the top priority. Would not be rational if the value of the weighting to be given a much higher human as 0.7 upwards because it means very little material value, which has a value that is considered.

Table 9 Value Weighting Safety

\begin{tabular}{|l|c|}
\hline \multicolumn{2}{|c|}{ Weighting } \\
\hline Human & 0,60 \\
\hline Property & 0,15 \\
\hline Environment & 0,15 \\
\hline Stakeholder & 0,10 \\
\hline
\end{tabular}

These results suggest that ran aground on the flow of events that have the highest risk then the second is a human accident, collision with a ship dock, and so on.

Table 10 Decrease Risk

\begin{tabular}{|c|c|c|c|c|c|c|c|c|c|c|c|c|c|c|c|c|c|c|c|c|c|c|c|c|}
\hline \multirow[b]{2}{*}{ accident } & \multicolumn{4}{|c|}{ Early risk } & \multicolumn{4}{|c|}{ TSP } & \multicolumn{4}{|c|}{ PPA } & \multicolumn{4}{|c|}{ PPM } & \multicolumn{4}{|c|}{ PAP } & \multicolumn{4}{|c|}{ PPB } \\
\hline & 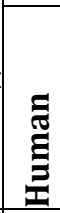 & 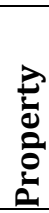 & 总 & 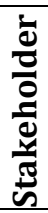 & $\underset{\Xi}{\Xi}$ & 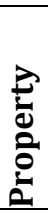 & 㿣 & $\begin{array}{l}\frac{0}{0} \\
\frac{0}{0} \\
\frac{0}{0} \\
\frac{1}{\pi} \\
\text { ஸे }\end{array}$ & 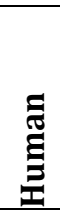 & 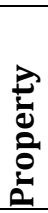 & 密 & 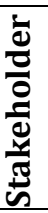 & 胥 & 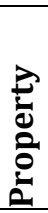 & 兽 & 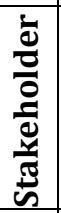 & $\underset{\Xi}{\Xi}$ & 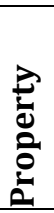 & 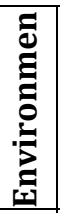 & 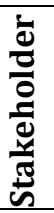 & 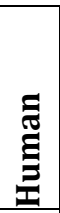 & $\begin{array}{l}2 \\
0 \\
0 \\
0 \\
0 \\
0 \\
0\end{array}$ & 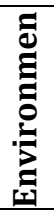 & $\begin{array}{l}\frac{1}{0} \\
\frac{0}{0} \\
\frac{1}{0} \\
\frac{x}{\pi} \\
\text { ஸ் }\end{array}$ \\
\hline aground & 6 & 6 & 0 & 6 & 5 & 5 & 0 & 5 & 2 & 2 & 0 & 2 & - & - & - & - & - & - & - & - & - & - & - & - \\
\hline $\begin{array}{c}\text { Human } \\
\text { accident }\end{array}$ & 6 & 7 & 3 & 6 & - & - & - & - & - & - & - & - & 3 & 4 & 0 & 3 & - & - & - & - & 2 & 3 & 0 & 2 \\
\hline $\begin{array}{c}\text { collision } \\
\text { ship } \\
\text { with } \\
\text { dock }\end{array}$ & 6 & 0 & 0 & 3 & - & - & - & - & - & - & - & - & - & - & - & - & 3 & 0 & 0 & 0 & - & - & - & - \\
\hline Sink & 3 & 6 & 0 & 3 & 2 & 5 & 0 & 2 & - & - & - & - & - & - & - & - & - & - & - & - & 0 & 3 & 0 & 0 \\
\hline
\end{tabular}


Table 11 Risk Lowers Cost

\begin{tabular}{|c|c|c|c|c|c|}
\hline \multirow{2}{*}{ countermeasures } & \multirow{2}{*}{$\begin{array}{l}\text { Charge } \\
\text { countermeas } \\
\text { ures }(\Delta C)\end{array}$} & \multicolumn{4}{|c|}{ benefit $(\Delta B)$} \\
\hline & & aground & $\begin{array}{l}\text { Human } \\
\text { accident }\end{array}$ & $\begin{array}{l}\text { Collision ship } \\
\text { with dock }\end{array}$ & Sink \\
\hline $\begin{array}{l}\text { 1. Training and Certification } \\
\text { Seafarers (PSP) }\end{array}$ & 991 million & 150 million & & & 250 million \\
\hline $\begin{array}{l}\text { 2. Routine Patrol and Installation } \\
\text { of signs Flow Ports (PPA) }\end{array}$ & 1,3 billion & 600 million & & & \\
\hline 3. Human Rescue Training (PPM) & 836 million & & 500 million & & \\
\hline 4. Tighten the port area (PAP) & 280 million & & & 30 million & \\
\hline $\begin{array}{l}\text { 5. Tightens Supervision Sailing } \\
\text { Permit (PPB) }\end{array}$ & 1,4 billion & & 500 million & & 500 million \\
\hline
\end{tabular}

Table 12 Calculation ICAR

\begin{tabular}{|c|c|c|c|c|c|c|c|c|}
\hline \multirow[t]{2}{*}{ countermeasures } & \multicolumn{4}{|c|}{$\begin{array}{l}\text { Reduction } \\
\text { risk }\end{array}$} & \multicolumn{4}{|l|}{ ICAR } \\
\hline & $\mathbf{A}$ & $\mathbf{B}$ & $\mathbf{C}$ & D & $\mathbf{A}$ & B & $\mathbf{C}$ & D \\
\hline $\begin{array}{l}\text { 1. Training and Certification } \\
\text { Seafarers (PSP) }\end{array}$ & 1 & & & 1 & $\begin{array}{l}841 \\
\text { million }\end{array}$ & & & $\begin{array}{l}741 \\
\text { million }\end{array}$ \\
\hline $\begin{array}{l}\text { 2. Routine Patrol and Installation of signs Flow } \\
\text { Ports (PPA) }\end{array}$ & 3 & & & & $\begin{array}{l}234 \\
\text { million }\end{array}$ & & & \\
\hline 3. Human Rescue Training (PPM) & & 3 & & & & $\begin{array}{l}112 \\
\text { million }\end{array}$ & & \\
\hline 4. Tighten the port area (PAP) & & & 3 & & & & $\begin{array}{l}84 \\
\text { million }\end{array}$ & \\
\hline 5. Tightens Supervision Sailing Permit (PPB) & & 1 & & 2 & & $\begin{array}{l}900 \\
\text { million }\end{array}$ & & $\begin{array}{l}450 \\
\text { million }\end{array}$ \\
\hline
\end{tabular}

Specification: A =Shattered Human, $\mathrm{B}=$ Accidents, C = Collision Ship Pier, D = Drowning

\section{Conclusion}

The results of the analysis conducted were concluded as follows.

- The number of ship accidents in Surabaya East Shipping Channel is quite high. This is evident from the total accidents along the 5 years (2009 s / d in 2013) as many as 26 cases. Having carried out the calculations, of the six types of accidents that can occur in four types of accidents at high risk, namely:

- $\quad$ Shattered, the value of risk 6

- $\quad$ Accident Man, with the value of risk 7

- $\quad$ Collision ship to dock, the value of risk 7

- Vessel Sink, with a value of risk 6

- The fourth type of accident is not allowed to enter the zone and should be risk reduction measures in a way to know in advance the fourth leading cause of the accident types.

- The main cause of these four vessels with a high risk of accident is Causes generally because of the narrowness of the plot, one of the considerations, or bad weather (wind, currents, and waves). Damage is most likely to occur plate damage, delay departure or dock, the main cause of accidents is human too many workers/porter competing wild, and dock ship collision that occurred at the time the ship will be mooring/docking at the port with the cause, among others, the motor is not working properly when the ship docked dark, strong currents, bad weather, and others, the main cause of the sinking ship is overloaded. 
- As for measures to reduce the risk to the fourth-highest accident is as follows.

- Shattered done with routine patrols and installation of signs groove port ICAR has amounted to 234 million to flow more orderly and safe so avoid the risk of the ship aground.

- Human Accidents can be prevented by a human rescue training vessel which has a value of 112 million ICAR, this is done so that the crew familiar and proficient in carrying out a rescue in case of accident onboard personnel.

- Collision ship to the pier by way of tightening the port area with ICAR 84 million so that unauthorized parties do not enter the port area.

- Vessel Sink with sailing permit tightening that has ICAR 450 million, so that does not happen again overloaded and each vessel is fully compliant with safety regulations.

From the results of this paper, we suggest reducing accidents that can have a large impact on both human and material casualties that risk reduction to reduce shipping aground east of Surabaya is to change the shipping route to avoid highrisk areas and the port carry out routine patrols and checking signs port groove. Then for human accidents during mooring boat will require decisive action from the port operators to tighten the dock area so as not to enter any unauthorized parties, for the ship to dock collision risk reduction is done by tightening the port that is not accessible by people who are not interested and last to reduce the risk of sinking in the shipping channel east of Surabaya should be done by tightening the sailing license.

\section{Compliance with ethical standards}

\section{Acknowledgments}

The authors greatly acknowledge the support from Indonesia Naval Technology College, STTAL Surabaya Indonesia for providing the necessary resources to carry out this research work. The authors are also grateful to the anonymous reviewers and journal editorial board for their many insightful comments, which have significantly improved this article.

\section{Disclosure of conflict of interest}

The authors declared no potential conflicts of interest concerning the research, authorship, and/or publication of this article.

\section{References}

[1] Artana, K Buda. The Risk Assessment Process, Class Reliability Systems Engineering, Reliability and Safety Laboratory, Department of Mechanical Systems Shipping FTK ITS, Surabaya. 2017.

[2] Branch, Alan E. Element of Shipping, Champaran \& Hall, Glasgow Press, London. 2016.

[3] HSE. Reducing Risk, Protecting People, Discusión Document, and London. 2019.

[4] IEC. "IEC 60300-3-9: Risk analysis of technological systems", International Electrotechnical Commission, Geneva. 2019.

[5] IMO. Guidelines for the FSA for use in the IMO Rule Making Process, MSC / Circ.1023 and MEPC / Circ.392, London. 2012.

[6] IMO. A Guide to Risk Assessment in Ship Operations, IACS, London. 2014.

[7] National Transportation Safety Committee (NTSC). Marine Safety Digest, Jakarta. 2017.

[8] Kristiansen, Svein. Maritime Transportation Safety Management and Risk Analysis, Elsevier Butter worth Heinemann, London. 2015.

[9] Mamduh M Hanafi. Risk Management, UPP STIM YKPN. 2019.

[10] Marine Safety Agency. Formal Safety Assessment MSC66 / 14. London. 2013.

[11] Port \& Harbour Risk Assessment and Safety Management System in New Zealand, in Maritime Safety, New Zealand. 2004. 